УДК 353

DOI: https://doi.org/10.32689/2618-0065-2019-2/1-84-94

Литвин Наталія Михайлівна, Член Всеукраїнської асамблеї докторів наук 3 державного управління, старший викладач кафедри публічного адміністрування Міжрегіональної Академії управління персоналом, 03039, м. Київ, вул. Фрометівська, 2, тел.: (073) 008-09-03, e-mail: id.vip.777@ukr.net

ORCID: 0000-0003-0120-3443

\title{
АНАЛІЗ ДОТАЦІЙНОСТІ МІСЦЕВИХ БЮДЖЕТІВ УКРАЇНИ
}

Анотація. На сьогодні одним із визначальних напрямів розвитку України є децентралізація державної влади з допомогою розвитку інституту місцевого самоврядування.

Ефективність функціонування місцевої влади безпосередньо залежить від потенціалу регіону та можливості якісного надання суспільних благ місцевому населенню, що тісно взаємопов'язано з ефективним управлінням фінансовими ресурсами на місцевому рівні.

Благополуччя держави залежить від стану місцевих бюджетів. Тому вкрай важливо дати можливість органам місцевого самоврядування функціонувати автономно, виступати центром розвитку, створювати суспільні блага, інновації та науково-технічний прогрес. Отже, фінансова забезпеченість i самостійність місцевих громад $€$ невід'ємними характеристиками спроможності місцевого самоврядування як такого.

Наразі в Україні місцеві бюджети не відповідають покладеним на них повноваженням. Відсутня належна фінансова база на утримання муніципальних установ, які передані органам місцевого самоврядування, на території яких ці установи розташовані, і чиє населення вони обслуговують. Наприклад, школи, медичні пункти, як правило, обслуговують жителів одного міста і їхній зміст віднесено до компетенції органів місцевого самоврядування. Тобто, держава передає повноваження місцевим органам влади без фінансового забезпечення виконання цих зобов'язань.

Аналіз дотаційності місцевих бюджетів вказує наскільки органи місцевого самоврядування в Україні фінансово спроможні повною мірою вирішувати питання місцевого значення. Іншими словами, стан місцевих бюджетів відображає наскільки держава у своїй політиці прагне досягти цілі, визначені Конституцією. Адже, у Конституції місцеве самоврядування визначено як право й реальна можливість місцевих громад самостійно у своїх інтересах і під свою відповідальність вирішувати питання місцевого значення. 
Саме на питання про те, чи реалізується це право й чи надана для цього реальна можливість територіальним громадам, вказує стан місцевих бюджетів.

Тому наявність гідного фінансового забезпечення $є$ найважливішим елементом для самостійності та незалежності об'єднаних територіальних громад. Наскільки буде розвинене місцеве самоврядування у фінансовоекономічному плані, настільки буде сильна держава. Без зміцнення фінансової основи місцевого самоврядування, підвищення фінансової самостійності місцевих громад неможливо домогтися ефективності місцевого самоврядування та наданих муніципальними органами якісних громадських послуг населенню.

Ключові слова: місцеве самоврядування, місцеві бюджети, дотації, дотаційність місцевих бюджетів.

Lytvyn Nataliia Mykhailivna, Member of the Ukrainian Assembly of Doctors of Science in Public Administration, Senior Lecturer of the Department of Public Administration, Interregional Academy of Personnel Management, 03039, Kyiv, Str. Frometivska, 2, tel.: (073) 008-09-03, e-mail: id.vip.777@ukr.net

ORCID: 0000-0003-0120-3443

\section{ANALYSIS OF SUBSIDIES OF LOCAL BUDGETS OF UKRAINE}

Annotation: One of the main directions of development of Ukraine is the decentralization of state power through the development of the institution of local self-government.

In particular, the effectiveness of the functioning of local authorities is directly dependent on the potential of the region and the possibility of the qualitative provision of public goods to the local population, which is closely linked to the effective management of financial resources at the local level.

The welfare of the state depends on the state of local budgets. It is extremely important to allow local governments to function autonomously, act as a center of development, create public goods, innovations and scientific and technological progress. Consequently, financial security and autonomy of local communities are inherent characteristics of the ability of local government as such.

Now in Ukraine, local budgets do not correspond to the powers vested in them. There is no adequate financial base for the maintenance of municipal institutions transferred to local governments in whose territory these institutions are located, and whose population they serve. For example, schools, medical stations, as a rule, serve the residents of one city, and their content is within the competence of local governments. That is, the state transfers powers to local authorities without financial support for the fulfillment of these obligations.

The analysis of subsidies to local budgets in general indicates how much local governments in Ukraine are financially capable of fully resolving issues of 
local significance. In other words, the state of local budgets indicates how much the state in its policy seeks to achieve the goals defined by the Constitution. Indeed, in the Constitution, local self-government is defined as the right and the real possibility of local communities independently in their own interests and under their responsibility to resolve issues of local significance.

It is the question of whether this right is being exercised and whether a real opportunity for territorial communities is provided for this, indicates the state of local budgets.

The availability of decent financial support is an essential element for the independence and independence of the united territorial communities. As far as local government is developed in financial and economic terms, so will be a strong state. Without strengthening the financial basis of local self-government, increasing the financial independence of local communities, it is impossible to achieve the effectiveness of local self-government and the quality public services provided by municipal services.

Key words: local government, local budgets, subsidies, subsidies to local budgets.

Постановка проблеми. Одним 3 основних принципів побудови бюджетної системи є принцип збалансованості, тобто надані повноваження на здійснення витрат кожного бюджету мають відповідати обсягу передбачених чинним законодавством надходжень бюджету на відповідний бюджетний рік. Тому необхідно проаналізувати рівень дотаційності місцевих бюджетів для розуміння наскільки місцеві громади фінансово спроможні виконувати покладені на них функції.

Аналіз останніх досліджень і публікацій. Проблематиці дослідженню місцевих бюджетів присвячені праці вітчизняних вчених: О. Василика, В. Гейця, М. Долішного, Б. Кваснюка, О. Кириленко, Т. Ковальчука, В. Кравченка, В. Лагутіна, І. Луніної, В. Опаріна, В. Федосова, І.Чугунова, Н. Чумаченка, А. Чухна, С. Юрія та ін. Однак, з огляду на великий перелік наукових праць, майже відсутні наукові розробки присвячені безпосередньо аналізу дотаційності регіонів.

Формулювання цілей статті. Метою статті $є$ аналіз сучасного стану дотаційності місцевих бюджетів України та визначення напрямків щодо покращення їхнього стану.

Виклад основного матеріалу дослідження. Місцеві бюджети $\epsilon$ фінансовою базою органів місцевого самоврядування та вирішальним чинником регіонального розвитку, тому їм належить особливе місце в економічній системі нашої держави [5]. Рівень формування місцевих бюджетів $\epsilon$ умовою й результатом соціально-економічного розвитку країни. Тому створення ефективного механізму формування місцевих бюджетів виступає однією 3 актуальних проблем, від вирішення якої залежатиме зростання економіки держави загалом. 
В Україні ключовою проблемою місцевих органів влади $є$ їхній високий рівень дотаційності (див табл. 1.), отже, громади не мають адекватного наповнення бюджетів фінансовими ресурсами, це зумовлює погіршення соціально-економічного стану багатьох регіонів України.

Кириленко О. П. стверджує, що з розширенням кількості дотаційних територій і включенням до їх складу всіх адміністративно-територіальних одиниць міжбюджетні трансферти перетворюються із важеля бюджетного регулювання й надання фінансової допомоги бідним регіонам в інструмент перерозподільних процесів [5, с.96]. Власюк Н. І. вважає, що застосовуваний принцип покриття нестачі фінансових ресурсів у регіонах трансфертами 3 державного бюджету $\epsilon$ дестимулятивним для активізації внутрішнього потенціалу розвитку регіонів [6, с. 181]. Отже, масштаб дотаційності місцевих бюджетів створює реальну загрозу економіці країни в цілому, що припускає необхідність всебічного дослідження цього явища й пошуку оптимальних шляхів щодо його подолання.

На сьогодні розвиток реформ місцевого самоврядування вимагає створення нових механізмів взаємовідносин державних органів влади й місцевих громад для забезпечення ефективного формування та виконання місцевих бюджетів. Також необхідні нові умови щодо розвитку бюджетного процесу на рівні місцевого самоврядування. Необхідне створення сприятливих умов щодо забезпечення фінансовими ресурсами місцевих бюджетів незалежно від їхнього географічного розташування або особливостей території.

Аналіз рівня дотаційності місцевих бюджетів за 2018 рік представлений у таблиці 1 , який вказує на несприятливу тенденцію, а саме, що на сьогодні фінансова основа місцевих громад істотно послаблена.

\begin{tabular}{|c|c|c|c|c|c|c|c|c|c|c|}
\hline Область & 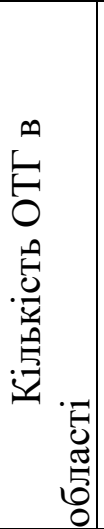 & 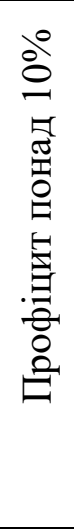 & 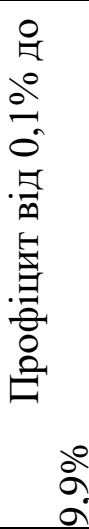 & 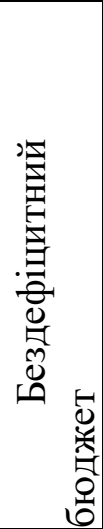 & 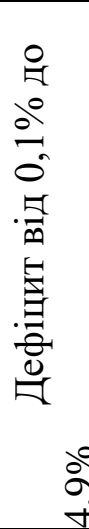 & 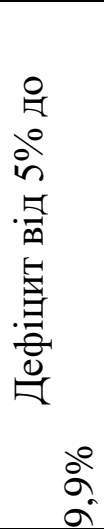 & 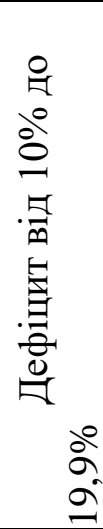 & 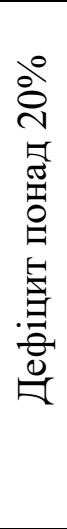 & 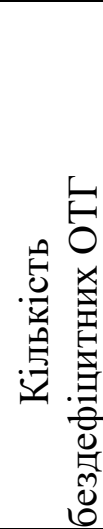 & 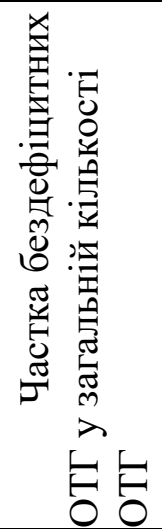 \\
\hline Вінницька & 4 & & & & & & 0 & & 2 & $5,3 \%^{3}$ \\
\hline Волинська & 0 & & & & & & & 0 & & $7,5 \%{ }^{1}$ \\
\hline $\begin{array}{l}\text { Дніпропет } \\
\text { ровська }\end{array}$ & 6 & & & & 0 & 1 & 3 & & 8 & $2,1 \%^{3}$ \\
\hline Донецька & & & & & & & & & & $6,7 \%$ \\
\hline
\end{tabular}




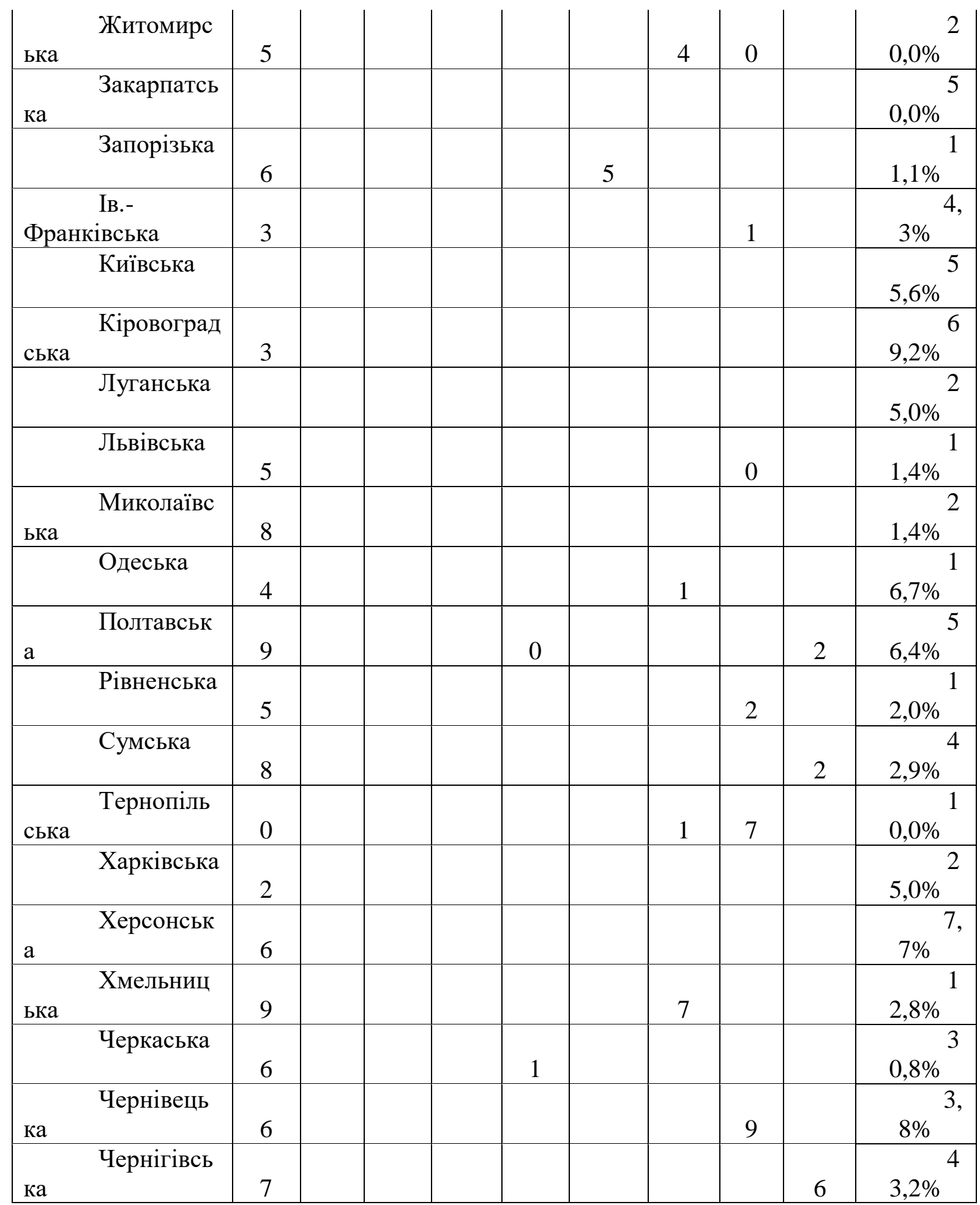

Розроблено автором на основі відкритих джерел

Аналіз проводився за підсумками 2018 року, показники характеризують фінансову достатність діяльності об'єднаних територіальних громад, а саме: частку бездефіцитних ОТГ у загальній кількості ОТГ в Україні у відсотковому відношенні, показник профіциту в діапазоні від $0,1 \%$ до $9,9 \%$, а також профіцит понад $10 \%$ в області, загальна кількість 
збалансованих бюджетів ОТГ області, дефіцит від 0,1\% до 19,9\%, та дефіцит понад $20 \%$.

Для проведення аналізу автор статті згрупував 664 ОТГ у відсотковому відношенні щодо бездефіцитних бюджетів ОТГ в Україні.

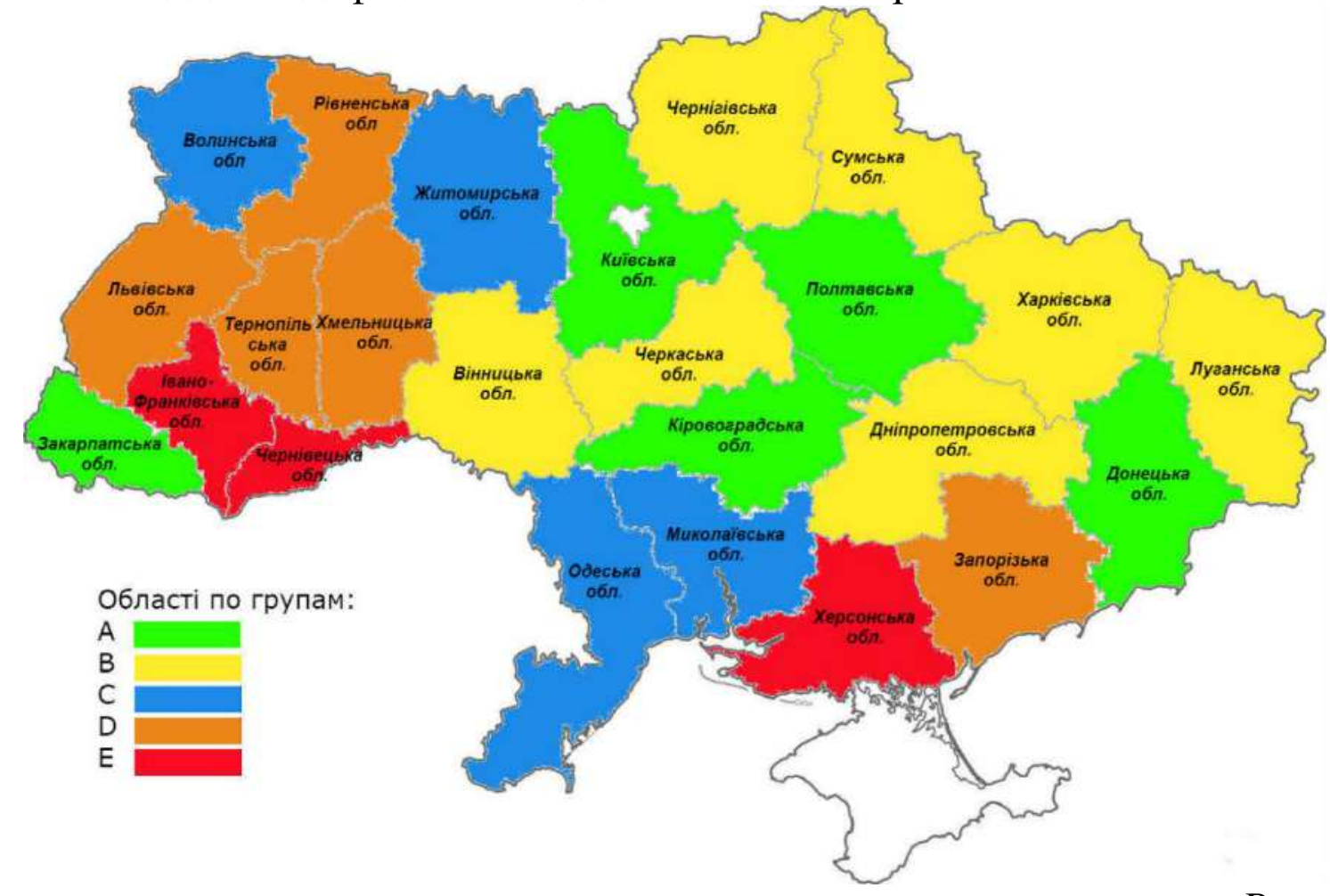

Puc. 1.

Розроблено автором на основі власного аналізу

Група А - група в якій частка бездефіцитних ОТГ у загальній кількості ОТГ рівняється $50 \%$ і вище відсотків.

Група В - група в якій частка бездефіцитних ОТГ у загальній кількості ОТГ від 25\% до $50 \%$.

Група С - група в якій частка бездефіцитних ОТГ у загальній кількості ОТГ від $15 \%$ до $25 \%$.

Група D - група в якій частка бездефіцитних ОТГ у загальній кількості ОТГ від 10\% до $15 \%$.

Група Е - група в якій частка бездефіцитних ОТГ у загальній кількості ОТГ від $0 \%$ до $10 \%$.

Вінницька область входить до групи $\mathrm{B}$ із показником $35,3 \%$ бездефіцитних ОТГ від загальної їх кількості. Слід зазначити, що 9 ОТГ мають профіцит у діапазоні від $0,1 \%$ до 9,9\%, а 3 ОТГ мають збалансований бюджет. Але незважаючи на це більша частина бюджетів ОТГ області $є$ дефіцитними. Зокрема, 22 ОТГ мають дефіцит, з яких 6 ОТГ мають дефіцит понад $20 \%$.

Волинська область входить до групи С. Показник бездефіцитних ОТГ становить 17,5\% від їхньої загальної кількості. Профіцит у діапазоні від 0,1\% до 9,9\% мають 5 ОТГ, від 10\% і більше - 2 ОТГ. Попри це, більша частина 
бюджетів ОТГ Волинської області є дефіцитними. Загалом налічується 33 ОТГ з дефіцитними бюджетами, 20 із яких мають дефіцит у діапазоні понад $20 \%$.

Дніпропетровська область входить до групи В. Бездефіцитні ОТГ складають $32,1 \%$ від загальної їх кількості. Профіцит у діапазоні від $0,1 \%$ до 9,9\% у 3 ОТГ, понад 10\% - 6 ОТГ, збалансований бюджет мають 9 ОТГ. Але здебільшого бюджети ОТГ Дніпропетровської області все ж таки залишаються дефіцитними. Усього налічується 38 ОТГ які мають дефіцит, 4 ОТГ із яких мають дефіцит у діапазоні більш ніж $20 \%$.

Донецька область входить до групи А 3 показником $66,7 \%$ бездефіцитних ОТГ від їхньої загальної кількості. Зокрема, 4 ОТГ мають профіцит у діапазоні від $0,1 \%$ до 9,9\%, а 2 ОТГ мають збалансований бюджет. Але, незважаючи на це, у Донецькій області є ОТГ, котрі мають дефіцитні бюджети. Загалом дефіцитних 3 ОТГ, із яких дефіцит у діапазоні понад 20\% мають 2 ОТГ.

Житомирська область входить до групи С. Показник бездефіцитних ОТГ становить 20\% від їхньої загальної кількості. Слід зазначити, що 5 ОТГ мають профіцит у діапазоні від $0,1 \%$ до 9,9\%, від 10\% і більше - 2 ОТГ, збалансований бюджет у 2 ОТГ. Попри це, більша частина бюджетів ОТГ Житомирської області $є$ дефіцитними. Загальна кількість дефіцитних бюджетів складає 36 ОТГ, із яких 10 ОТГ мають більш ніж 20\% дефіциту.

Закарпатська область входить до групи А із показником $50 \%$ бездефіцитних ОТГ від загальної їх кількості. Профіцит у діапазоні від $0,1 \%$ до 9,9\% у 1 ОТГ, а збалансований бюджет мають 2 ОТГ. Зокрема, у Закарпатській області дефіцитними $є$ половина бюджетів ОТГ. Усього налічується 3 дефіцитних ОТГ, 1 ОТГ із яких має дефіцит понад 20\%.

Запорізька область входить до групи $\mathrm{D}$ із показником $11,1 \%$ бездефіцитних ОТГ від їхньої загальної кількості. Усього 2 ОТГ мають профіцит у діапазоні від $0,1 \%$ до 9,9\%, а збалансований бюджет у 2 ОТГ. Слід зазначити, що здебільшого бюджети ОТГ області є дефіцитними. А саме, 32 ОТГ є дефіцитними, 3 ОТГ із яких мають дефіцит понад 20\%.

Івано-Франківська область входить до групи Е. Бездефіцитні ОТГ складають 4,3\% від загальної їх кількості. Лише 1 ОТГ має профіцит у діапазоні від 0,1\% до 9,9\%. Із загальної кількості об'єднаних територіальних громад Івано-Франківської області (всього 23 ОТГ) 22 ОТГ є дефіцитними, із яких 21 ОТГ має дефіцит у діапазоні понад 20\%.

Київська область входить до групи А із показником 55,6\% бездефіцитних ОТГ від їхньої загальної кількості. Варто зазначити, що 3 ОТГ мають профіцит у діапазоні від $0,1 \%$ до 9,9\%, профіцит понад $10 \%$ - 1 ОТГ, а збалансований бюджет у 1 ОТГ. Незважаючи на те, що здебільшого бюджети ОТГ Київської області є бездефіцитними, усе таки є об'єднані територіальні громади із дефіцитними бюджетами, зокрема, їхня кількість становить 4 ОТГ. 
Кіровоградська область входить до групи А. Показник бездефіцитних ОТГ становить 69,2\% від загальної їх кількості. Загалом 5 ОТГ мають профіцит у діапазоні від 0,1\% до 9,9\%, профіцит від 10\% - 1 ОТГ, а 3 ОТГ мають збалансований бюджет. Зважаючи на те що більша частина бюджетів ОТГ області є бездефіцитними, слід зазначити що 4 ОТГ мають дефіцит.

Луганська область входить до групи В із показником 25\% бездефіцитних ОТГ від їхньої загальної кількості. Профіцит у діапазоні від $0,1 \%$ до 9,9\% має 1 ОТГ, збалансований бюджет має також 1 ОТГ. Незважаючи на це, загальна кількість дефіцитних бюджетів в області - 6 ОТГ, із яких 3 ОТГ мають більш ніж 20\% дефіциту.

Львівська область входить до групи D та має показник 11,4\% бездефіцитних ОТГ від загальної їх кількості. Усього в області 4 ОТГ які мають профіцит у діапазоні від $0,1 \%$ до 9,9\%. Здебільшого бюджети області залишаються дефіцитними, зокрема, їхня кількість складає 31 ОТГ, із яких 20 ОТГ мають дефіцит понад $20 \%$.

Миколаївська область входить до групи С. Показник бездефіцитних ОТГ складає 21,4\% від їхньої загальної кількості. Загалом 4 ОТГ мають профіцит у діапазоні від $0,1 \%$ до 9,9\%, 1 ОТГ має профіцит понад $10 \%$, а збалансований бюджет - 1 ОТГ. Слід зазначити, що здебільшого бюджети області є дефіцитними. А саме, дефіцитний бюджет мають 22 ОТГ, із яких дефіцит понад 20\% має 1 ОТГ.

Одеська область входить до групи С із показником $16,7 \%$ бездефіцитних ОТГ від їхньої загальної кількості. В області є 3 ОТГ котрі мають профіцит у діапазоні від $0,1 \%$ до 9,9\% та 1 ОТГ яка має збалансований бюджет. Попри це більшість бюджетів Одеської області залишаються дефіцитними. Загалом дефіцитних бюджетів налічується 20 ОТГ, із яких 4 ОТГ мають дефіцит понад $20 \%$.

Полтавська область входить до групи А, та має показник 56,4\% бездефіцитних ОТГ від загальної їх кількості. Варто зазначити, що 8 ОТГ мають профіцит у діапазоні від $0,1 \%$ до 9,9\%, профіцит понад $10 \%$ - 6 ОТГ, а в 8 ОТГ збалансований бюджет. Незважаючи на те що здебільшого ОТГ мають бездефіцитні бюджети, є в області й дефіцитні ОТГ. А саме 17 ОТГ мають дефіцитні бюджети, із яких понад $20 \%$ дефіциту має 1 ОТГ.

Рівненська область входить до групи D. Показник бездефіцитних ОТГ складає $17 \%$ від їхньої загальної кількості. Лише 2 ОТГ мають профіцит у діапазоні від $0,1 \%$ до 9,9\% та 1 ОТГ має збалансований бюджет. Більша кількість ОТГ області є дефіцитними, загалом їхня кількість складає 22 ОТГ, із яких 12 ОТГ мають дефіцит понад 20\%.

Сумська область входить до групи В із показником 42,9\% бездефіцитних ОТГ від загальної їх кількості. В області налічується 3 ОТГ які мають профіцит у діапазоні від 0,1\% до 9,9\%, 2 ОТГ мають профіцит понад 10\%, збалансований бюджет мають 7 ОТГ. Слід зазначити, що 
здебільшого бюджети ОТГ Сумської області є дефіцитними. Зокрема, 16 ОТГ мають дефіцитні бюджети, із яких дефіцит понад 20\% є у 2 ОТГ.

Тернопільська область входить до групи D та має показник $10 \%$ бездефіцитних ОТГ від загальної їх кількості. Профіцитною $є 1$ ОТГ із діапазоном від 0,1\% до 9,9\%, також 1 ОТГ має профіцит понад 10\%, 2 ОТГ мають збалансований бюджет. Значна кількість бюджетів області $\epsilon$ дефіцитними, їхня кількість складає 36 ОТГ, із яких 17 ОТГ мають дефіцит понад $20 \%$.

Харківська область входить до групи В. Показник бездефіцитних ОТГ складає 25\% від їхньої загальної кількості. В області є 1 ОТГ яка має профіцит у діапазоні від $0,1 \%$ до 9,9\%, профіцит понад $10 \%$, - 1 ОТГ, та 1 ОТГ має збалансований бюджет. Слід зауважити, що більша частина Харківських ОТГ є дефіцитними, їхня загальна кількість в області - 9 ОТГ.

Херсонська область входить до групи Е 3 показником $7,7 \%$ бездефіцитних ОТГ від загальної їх кількості. Лише 1 ОТГ має профіцит у діапазоні від $0,1 \%$ до $9,9 \%$ та 1 ОТГ зі збалансованим бюджетом. Слід зазначити, що майже всі ОТГ є дефіцитними, їхня кількість складає 24 ОТГ, із яких 5 ОТГ мають дефіцит понад $20 \%$.

Хмельницька область входить до групи D із показником $12,8 \%$ бездефіцитних ОТГ від загальної їх кількості. В області налічується 3 ОТГ які мають профіцит у діапазоні від $0,1 \%$ до 9,9\%, 1 ОТГ має профіцит понад $10 \%$ та 1 ОТГ має збалансований бюджет. Але більша частина бюджетів ОТГ області є дефіцитними. Зокрема, 34 ОТГ мають дефіцит, з яких 7 ОТГ мають більш ніж $20 \%$ дефіциту.

Черкаська область входить до групи В. Показник бездефіцитних ОТГ складає 30,8\% від їхньої загальної кількості. Варто зазначити, що 3 ОТГ мають профіцит у діапазоні від $0,1 \%$ до 9,9\%, профіцит понад $10 \%$ - 1 ОТГ, збалансований бюджет у 4 ОТГ. Але більша частина ОТГ Черкаської області $€$ дефіцитними, їхня загальна кількість складає 18 ОТГ.

Чернівецька область входить до групи Е 3 найнижчим показником в Україні 3,8\% бездефіцитних ОТГ від загальної їх кількості. Лише 1 ОТГ має профіцит у діапазоні від $0,1 \%$ до 9,9\%. Від загальної кількості ОТГ в області (всього 26 ОТГ) дефіцитними є 25 ОТГ, із яких 19 ОТГ мають дефіцит понад $20 \%$.

Чернігівська область входить до групи В та має показник 43,2\% бездефіцитних ОТГ від загальної їх кількості. В області налічується 5 ОТГ які мають профіцит у діапазоні від 0,1\% до 9,9\%, профіцит понад $10 \%$ - 3 ОТГ, збалансований бюджет у 8 ОТГ. Але незважаючи на це більшість бюджетів є дефіцитними. Зокрема, в області дефіцитні 21 ОТГ, із яких дефіцит понад $20 \%$ у 1 ОТГ.

3 проведеного аналізу можна побачити що із 664 об'єднаних територіальних громад, здебільшого велика кількість ОТГ так і залишилися дотаційними. Так, 12 областей, а це половина зі списку, знаходяться в групах 
C, D i E. Тобто в них частка бездефіцитних ОТГ у загальній кількості ОТГ не перевищує $25 \%$.

Висновки. Актуальною і гострою проблемою на сьогодні $є$ стан місцевих бюджетів, який вказує на обмеженість фінансових ресурсів.

Наразі, держава передає повноваження місцевим органам влади без фінансового забезпечення на виконання цих зобов'язань. Як наслідок, невиконання частини публічних зобов'язань, так як зрозуміло, що функції й повноваження, що передаються місцевим органам без належного фінансування, не можуть виконуватися належним чином.

Повинна бути визначена мета політики вирівнювання бюджетної забезпеченості. Ця мета може полягати у вирівнюванні для досягнення мінімальної бюджетної забезпеченості, необхідної для вирішення питань місцевого значення в тому обсязі, щоб виконати гарантії держави рівного доступу до послуг, включно з послугами муніципальної інфраструктури. Для цього потрібно визначити стандарти цих послуг i розрахувати рівень мінімальної бюджетної забезпеченості.

\section{Лimepamypa:}

1. Бюджетний Кодекс України: Верховна Рада України; Кодекс України від 08.07.2010 № 2456-VI (із змінами й доповненнями). [Електронний ресурс]. - Режим доступу: http://zakon.rada.gov.ua.

2. Концепція реформування місцевого самоврядування та територіальної організації влади в Україні. Розпорядження Кабінету Міністрів України від 1 квітня 2014 p. №333-p. Режим доступу: http://zakon2.rada.gov.ua/.

3. Фінансово-монетарні важелі економічного розвитку: в 3 т/ за ред. A.I. Даниленко. - К: Фенікс, 2008. - Т.1. Фінансова політика та податково-бюджетні важелі їі реалізації. - с.308.

4. Данилишин Б., Настав час бюджетної федералізації України [Електронний pecypc] / Б. Данилишин // - Режим доступу: http://www. epravda.com.ua/columns/2012/12/17/351286/.

5. Місцеві фінанси: підручник / [О.П. Кириленко, О.Р. Квасовський, А.В. Лучка та ін.]; за ред. О.П. Кириленко. - К.: Знання, 2006. С. 96.

6. Власюк Н.І., Основні напрями реформування міжбюджетних відносин в Україні [Текст] / Н.І. Власюк // Збірник науковотехнічних праць. - Науковий вісник НЛТУ України, 2012. - Вип. 22.8. С. 181.

\section{References:}

1. Biudzhetnyi Kodeks Ukrainy [Budget Code of Ukraine]. (2010). Vidomosti Verkhovnoi Rady Ukrainy - Bulletin of Verkhovna Rada of Ukraine, 50-51 [in Ukrainian].

2. Rozporiadzhennia Kabinetu Ministriv Ukrainy "Kontseptsiia reformuvannia mistsevoho samovriaduvannia ta terytorialnoi orhanizatsii vlady v Ukraini” : vid 1 kvitnia 2014 r., № 333-r [Order of the Cabinet of Ministers of Ukraine "The concept of reforming local selfgovernment and territorial organization of power in Ukraine” from April 1 2014, № 333-r]. (n.d.). zakon.rada.gov.ua. Retrieved from https://zakon.rada.gov.ua/laws/show/333-2014\%D1\%80/stru [in Ukrainian].

3. Danylenko, A. I. (Eds.). (2008). Finansovo-monetarni vazheli ekonomichnoho rozvytku. T.1. Finansova polityka ta podatkovo-biudzhetni vazheli yii realizatsii [Financial and 
monetary instruments of economic development. Vol. 1. Financial policy and fiscal levers of its implementation]. Kyiv: Feniks [in Ukrainian].

4. Danylyshyn, B. (December 17, 2012). Nastav chas biudzhetnoi federalizatsii Ukrainy [The time has come for the budget federalization of Ukraine]. www.epravda.com.ua. Retrieved from http://www.epravda.com.ua/columns/2012/12/17/351286/ [in Ukrainian].

5. Kyrylenko, O.P., Kvasovskyi, O.R., Luchka, A.V., et. al. (2006). Mistsevi finansy [Local finances]. O. P. Kyrylenko (Eds.). Kyiv: Znannia [in Ukrainian].

6. Vlasiuk, N. I. (2012). Osnovni napriamy reformuvannia mizhbiudzhetnykh vidnosyn v Ukraini [Main Directions of Reforming Intergovernmental Fiscal Relations in Ukraine]. Naukovyi visnyk NLTU Ukrainy - Scientific Herald of NLTI of Ukraine, 22.8, 179-183 [in Ukrainian]. 